\title{
POLICIES TO CONTROL CANCER IN INFANTS AND JUVENILES IN BRAZIL
}

\author{
Regina Aparecida Garcia de Lima ${ }^{1}$
}

We have entered a new era for children and adolescents with cancer. For the first time in Brazil, the Ministry of Health, through the National Institute of Cancer (INCA), in partnership with the Brazilian Society of Pediatric Oncology (SOBOPE), has published a study covering the infant-juvenile cancer panorama (population less than 19 years) as well as health care organizations that deal with the problem.

The publication "Cancer in children and teenagers in Brazil: recorded data of population and mortality"(1), unpublished in national literature, is part of the action planned by the Forum for Integral Care to Children and Adolescents with Cancer, coordinated by the INCA together with representative health services, medical entities and non-governmental organizations dedicated to control infant-juvenile cancer.

Why is infant-juvenile cancer a priority on the agendas of the public health administration and focus of attention for health organizations?

In Brazil and in the world, pediatric and juvenile cancer is considered a public health problem due to its high mortality rate; high financial costs of treatment, detection, and diagnosis; and the economic resources wasted as a result of the decrease in human labor potential ${ }^{(2)}$.

Another reason is based on the change in the epidemic profile; infant-juvenile cancer is rare when compared to adults' cases, it corresponds to about 2 to $3 \%$ of all tumors in the country. Health indicators for children and teenagers point out that cancer has become a serious threat; it corresponds to the first cause of death by diseases in the age range from 5 to 19 years old, preceded by external causes only, such as accidents and violence ${ }^{(1)}$.

Opposite to adult tumors, infant-juvenile cancer differs in several aspects, like type, sites, etiologies, characteristics and treatments. In most cases, the origin of cancer is unknown, making prevention a greater challenge. Early diagnosis is the best alternative for successful treatment ${ }^{(1-2)}$.

The discussion about cancer control in Brazil highlights the inadequacy of oncological services and the importance of having a good balance between prevention and therapeutics. It also highlights the important role played by human resources, which are still behind the curve on technical-scientific knowledge and epidemic management information; also, they are insufficient in quantity and quality ${ }^{(3)}$; these same issues are found in the infant-juvenile cancer area.

Thus, law No 2.439/GM, related to the National Oncological Care Policies, determines that care must contemplate all levels (basic, intermediate and highly specialized care), to ensure the implementation of prevention, diagnosis, treatment, rehabilitation and palliative measures. The law determines that care should be organized in levels of hierarchy, establishing guidelines to guarantee efficient and integral care. It also emphasizes the need to improve human resources and foster permanent education programs for professionals who participate in the implementation of the Oncological Care Policies ${ }^{(4)}$.

Besides knowing the policies that involve cancer prevention and control, as well as a successful implementation of healthcare actions, it is necessary to identify biological, psycho-social and other aspects that are particular to infant-juvenile cancer. In this line of thought, we found that cancer diagnosis and therapeutic processes should begin with symptoms recognized by the parents and, when the diagnosis is confirmed, many times, the disease is already in an advanced stage. It is common, as well, that the diagnosis occurs by accident during a routinary physical exam; this can be explained by the lack of specific signs and symptoms in infantjuvenile cancer, like fever, paleness, cephalea, anorexia, bone pain and swollen ganglions, which can be associated and/or wrongly taken for signs and symptoms of other common childhood pathologies ${ }^{(1)}$.

${ }^{1}$ Member of the Editorial Board of the Latin American Journal of Nursing, Full Professor of the University of São Paulo at Ribeirão Preto College of Nursing WHO Collaborating Centre for Nursing Research Development, Brazil, e-mail: limare@eerp.usp.br. 
To achieve good results, the Permanent Forum of Integral Care to Children and Teenagers has proposed five points to control cancer in children and teenagers: 1) Partnership integration: development of a portal dedicated to integral care; 2) Diagnosis quality: elaboration of guidelines to help diagnosis; 3 ) Care quality: elaboration of a score-card to evaluate oncological pediatric services; 4) Communication and; 5) Identification of guidelines to implement integral care ${ }^{(1)}$.

It is hoped that these public policies, aimed at controlling infant-juvenile cancer, help to promote and support actions that guarantee access to diagnosis, obtain an efficient treatment and a long term follow up, seeking to increase the quality of life for children, teenagers and their families.

The recognition of infant-juvenile cancer as a public health problem requires collaboration and integration between public policies and scientific knowledge. In this respect, the undeniable contribution of nursing research should be acknowledged, which allowed for significant improvements in the care offered to children and adolescents with cancer.

\section{REFERENCES}

1. Instituto Nacional do Câncer (BR). Coordenação de Prevenção e Vigilância do Câncer. Câncer na criança e no adolescente no Brasil. Dados dos Registros de Base Populacional. Rio de Janeiro: Sociedade Brasileira de Oncologia Pediátrica (SOBOPE)/ Instituto Nacional do Câncer (INCA); 2008.

2. Ministério da Saúde (BR). Secretaria Nacional de Assistência à Saúde. Instituto Nacional do Câncer. Estimativa 2010: incidência do câncer no Brasil. Rio de Janeiro: INCA; 2009.

3. Kligerman J. Fundamentos para uma política nacional de prevenção e controle do câncer. Rev Bras Cancerol 2002; 48(1):3-7.

4. Ministério da Saúde (BR). Portaria No 2.439, de 08 de dezembro de 2005. Institui a Política Nacional de Atenção Oncológica: Promoção, Prevenção, Diagnóstico, Tratamento, Reabilitação e Cuidados Paliativos, a ser implantada em todas as unidades federadas, respeitadas as competências das três esferas de gestão [Internet]. Brasília. [Acesso 30 nov 2009]. Disponível em: http://bvsms.saude.gov.br/bvs/saudelegis/gm/2005/prt2439_08_12_2005.html 